http://ejurnal.ubharajaya.ac.id/index.php/EDUKARYA

\title{
Pembelajaran Project Based Learning - Literasi dalam Meningkatkan Kemampuan Penalaran Matematis Siswa di Sekolah Dasar
}

\author{
Zaenal Abidin ${ }^{1 *}$, Arief Cahyo Utomo², Vira Pratiwi ${ }^{3}$, Laely Farokhah ${ }^{4}$ \\ ${ }^{1,2}$ Pendidikan Guru Sekolah Dasar, Fakultas Keguruan dan Ilmu Pendidikan, Universitas \\ Muhammadiyah Surakarta, Jl. A. Yani Tromol Pos 1, Mendungan, Pabelan, Kec. Kartasura, \\ Kabupaten Sukoharjo, Jawa Tengah, 57162, Indonesia \\ ${ }^{3}$ Pendidikan Guru Sekolah Dasar, Fakultas Ilmu Pendidikan, Universitas Bhayangkara Jakarta \\ Raya \\ ${ }^{4}$ Pendidikan Guru Madrasah Ibtidaiyah, Fakultas Agama Islam, \\ Universitas Muhammadiyah Jakarta, Indonesia
e-mail: ${ }^{1} z a 825 @ u m s . a c . i d,{ }^{2}$ acu234@ums.ac.id, ${ }^{3}$ vira.pratiwi@dsn.ubharajaya.ac.id,
laelyfarokhah@umj.ac.id
*Korespondensi e-mail: ${ }^{1}$ za825@ums.ac.id

\begin{abstract}
The lower mathematical reasoning abilities of primary school students are the background of this research. This happens because students have not been properly facilitated to develop the ability mathematical of reasoning. Mathematics learning can develop reasoning ability well because mathematics learning has systematic concepts and conceptual relationships. This will have an impact on logical, systematic and rational ways of thinking. Therefore, teachers must be able to choose learning models that can facilitate the ability of mathematical reasoning. One learning model that can be used is the literacy project-based learning model. This study aimed to determine the effectiveness of improving the ability of mathematical reasoning students who obtain literacy project-based learning. Design of this research was used pretest-posttest nonequivalent control group. Based on research results, conclusions can be drawn about effectiveness of learning includes n-gain, minimum completeness criteria, and mastery learning. Literacy project-based learning has been effective in facilitating reasoning abilities. That is because literacy project-based learning can present contextual material with literacy works that are made and invited to carry out the process of thinking about the use of mathematical contexts in daily life. Furthermore, students can connect mathematical material with real-life contexts and make reasoning to interpret learning well.
\end{abstract}

Keywords: PJBL, Literacy, Reasoning Mathematics.

\begin{abstract}
Abstrak
Kemampuan penalaran matematika siswa sekolah dasar yang sangat adalah latar belakang penelitian ini. Hal tersebut terjadi karena siswa belum difasilitasi dengan baik untuk mengembangkan kemampuan penalaran matematika. Pembelajaran matematika dapat mengembangkan kemampuan penalaran dengan baik karena pembelajaran matematika memiliki konsep sistematis dan hubungan konseptual. Hal tersebut berdampak pada cara berpikir logis, sistematis dan rasional. Oleh karena itu, guru harus dapat memilih model pembelajaran yang dapat memfasilitasi kemampuan penalaran matematika. Salah satu model pembelajaran yang dapat digunakan adalah model pembelajaran Project Based learning - Literasi. Penelitian ini bertujuan untuk mengetahui efektivitas peningkatan kemampuan penalaran matematis siswa yang memperoleh pembelajaran Project Based learning - Literasi. Desain penelitian ini menggunakan pretest-posttest non-equivalent control group. Berdasarkan hasil penelitian, kesimpulan dapat ditarik tentang efektivitas pembelajaran yang mencakup n-gain, kriteria ketuntasan minimum, dan penguasaan pembelajaran. Pembelajaran Project Based learning - Literasi telah efektif dalam memfasilitasi kemampuan penalaran. Hal tersebut dikarenakan pembelajaran Project Based learning - Literasi dapat menyajikan materi kontekstual dengan karya-karya Literasi yang dibuat dan dituntut untuk melakukan proses berpikir tentang penggunaan konteks matematika dalam
\end{abstract}


kehidupan sehari-hari. Selain itu, siswa dapat menghubungkan materi matematika dengan konteks kehidupan nyata dan dapat membuat alasan untuk menafsirkan pembelajaran dengan baik.

Kata kunci: Project Based learning, Literasi, Penalaran Matematika.

\section{PENDAHULUAN}

Pada abad ke-21, perkembangan ilmu pengetahuan dan teknologi menuntut untuk mampu berpikir tingkat tinggi yang mencakup kritis, logis, kreatif. Trilling \& Fadel (2009) menyatakan pendidikan di abad ke-21 berfokus pada empat kompetensi yaitu kemampuan pemahaman yang tinggi, kemampuan berpikir kritis, kemampuan berkolaborasi, dan kemampuan berkomunikasi.

Keadaan siswa di Indonesia berbanding terbalik dengan tuntutan abad ke- 21 . Kompetensi siswa Indonesia masih sangat rendah. Hal tersebut bedasarkan hasil Trends in International Mathematic and Science Study (TIMSS) pada tahun 2015 yang menunjukkan hasil dari test siswa indonesia masih berada di posisi empat terbawah. Hasil test tersebut menunjukkan bahwa siswa SD di Indonesia masih kurang baik dalam kemampuan matematika.

Hasil TIMSS di atas menjelaskan bahwa siswa SD di Indonesia masih sangat rendah dalam kemampuan membaca pemahaman dalam bidang sains dan matematika, serta kemampuan memecahkan masalah yang berkaitan dengan konteks kehidupan sehari-hari. Siswa tersebut kurang terfasilitasi dengan baik dalam pengembangan kemampuan penalaran matematis siswa. Penalaran matematis dapat mengembangkan kemampuan berpikir logis yang menjadi tuntutan dari abad ke-21 (Abidin \& Jupri, 2017). Permasalahan tersebut terjadi dikarenakan siswa lebih sering mengerjakan soal rutin yang hanya melatih ingatan (Abidin, 2016). Selain itu, siswa tidak diberikan kesempatan untuk mencari dan menemukan pengetahuannya sendiri sehingga kemampuan penalaran matematis siswa belum terfasilitasi dengan maksimal.

Pembelajaran pada Kurikulum 2013 edisi revisi 2018, menyajikan materi dari konsep suatu materi bukan dari suatu permasalahan (Kemendikbud, 2016). Sehingga siswa kurang terfasilitasi kemampuan penalaran matematis. Siswa tidak diberikan permasalahan untuk mengembangkan kemampuan menduga, berpikir logis dan menyimpulkan informasi. Konteks kehidupan sehari-hari menjadi hal yang penting dalam mengembangkan kemampuan penalaran siswa, siswa akan berpikir secara induktif dan deduktif yang melatih berpikir logis (Mahdiansyah \& Rahmawati, 2014). Sehingga dengan adanya revisi Kurikulum ini, menyebabkan kurang terfasilitasinya kemampuan penalaran siswa dengan baik.

Pembelajaran yang menjelaskan penalaran dapat mengembangkan pola pikir anak secara logis, induktif dan deduktif (Firdaus, Wahyudin., \& Herman, 2017). Pembelajaran dan pemahaman konsep dapat diawali secara induktif melalui pengalaman peristiwa nyata. Pembelajaran harus dapat menghubungkan antara pengetahuan siswa dan konteks permasalahan. Sehingga guru harus bisa menentukan desain pembelajaran yang dapat memfasilitasi kemampuan penalaran matematis.

Model pembelajaran merupakan suatu rencana yang digunakan untuk membentuk kurikulum, membuat materi pembelajaran, dan menjadi pedoman pembelajaran (Joyce, Weil, \& Calhoun, 2009). Model dijabarkan menjadi sebuah kesatuan luas dari sistempembelajaran yang mengandung dasar filosofis khusus atau teori pembelajaran dengan metode pedagogik (Bhargava, 2016). Jadi model pembelajaran merupakan nyawa dalam membuat sebuah desain pembelajaran. Model Project Based Learning membantu siswa dalam membiasakan untuk berpikir secara induktif Abidin \& Jupri (2017). Model 
Project Based Learning merupakan sebuah model yang sangat cocok untuk semua jenjang pendidikan, karena menurut Etherington (2011) menjelaskan pembelajaran dengan Project Based Learning dapat membuat siswa memahami suatu masalah dan mencari solusinya sehingga siswa belajar secara bermakna. Hal tersebut sejalan dengan penelitian Firdaus, Wahyudin, \& Herman (2017) yang menjelaskan bahwa pembelajaran dengan Project Based Learning dapat membuat anak menghubungkan pengetahuan siswa dan konteks kehidupan sehari-hari dengan baik.

\section{Model Project Based Learning - Literasi}

Literasi merupakan hal sangat penting dalam pembelajaran abad ke-21. Sejalan dengan hal itu, Concannon-Gibney \& McCarthy (2012) menyatakan bahwa pembelajaran pada abad ke-21 harus selalu mendukung kegiatan literasi, agar pembelajaran dapat bermakna dan memberikan keterampilan kepada siswa. Sedangkan McKee \& Ogle (2005) memandang literasi merupakan keterampilan dalam menggunakan membaca, menulis, menyimak, dan berbicara secara efisien untuk memstimulus kemampuan berpikir dan berkomunikasi.

McConachi, et al. (2010) menggambarkan model pembelajaran PJBL-Literasi sebagai pembelajaran yang menuntut penggunaan membaca, logika, penelitian, berbicara dan menulis untuk mempelajari konten pengetahuan yang bersifat kompleks. Pendapat ini sejalan dengan Rahman (2018) yang menyatakan bahwa pembelajaran PJBL-Literasi merupakan pembelajaran yang memberikan tantangan kepada siswa untuk mengkaji dan menerapkan literasi praktis yang berfungsi sebagai alat mediasi untuk mempelajari berbagai konsep lintas kurikulum.

Shyyan, et al (2008). menjelaskan pembelajaran membaca yang diintegrasikan dengan matematika telah mampu meningkatkan kemampuan siswa dalam menguasai konsep matematika. Sedangkan Tan (2011). menjelaskan kemampuan siswa memahami konsep mengalami perkembangan yang signifikan ketika pembelajaran mengaplikasikan keterampilan literasi. Lebih lanjut, Swanson, et al. (2011) menjelaskan bahwa pembelajaran literasi mampu meningkatkan kemampuan membaca siswa sekaligus meningkatkan pemahaman siswa terhadap materi ajar.

Berdasarkan beberapa penelitian di atas upaya dalammengembangkan kemampuan belajar dan kompetensi abad ke-21 pada diri siswa dapat dilakukan dengan menerapkan keterampilan PJBL-Literasi. Pembelajaran dengan model PJBL-Literasi siswa akan mampu berpikir kritis, kreatif dan mampu pula berkolaborasi dan berkomunikasi secara efektif. Adapun langkah-langkah pembelajaran PJBL-Literasi telah dikembangkan oleh Bill \& Jamar (2010), langkah-langkah pembelajaran PJBL-Literasi dapat dilihat pada Tabel 1 di bawah ini.

Tabel 1. Model Pembelajaran PJBL-Literasi

\begin{tabular}{ll}
\hline \multicolumn{1}{c}{ Langkah } & \multicolumn{1}{c}{ Kegiatan Siswa } \\
\hline Set up & $\begin{array}{l}\text { Siswa diberikan penjelasan tentang rencana, } \\
\text { tujuan dna kegiatan pembelajaran yang akan } \\
\text { dilaksanakan. }\end{array}$ \\
\hline Explore & $\begin{array}{l}\text { Siswa melakukan kegiatan eksplorasi secara } \\
\text { individu dalam menyelesaikan tugas. }\end{array}$ \\
\hline
\end{tabular}




\begin{tabular}{ll}
\hline \multicolumn{1}{c}{ Langkah } & \multicolumn{1}{c}{ Kegiatan Siswa } \\
\hline & $\begin{array}{l}\text { Siswa melakukan kerjasama dengan teman } \\
\text { kelompoknya utnuk menyelesaikan tugas- } \\
\text { tugas yang lebih kompleks. } \\
\text { Siswa membuat kesimpulan dengan suatu } \\
\text { karya literasi (Pop up, Poster, Komik ). }\end{array}$ \\
\hline Share and Discuss & Siswa mendiskusikan berbagai solusi. \\
\hline Presenting & Siswa menjelaskan karya yang telah dibuat. \\
\hline
\end{tabular}

\section{METODE PENELITIAN}

Dalam penelitian ini menggunakan metode eksperimen dengan desain kuasi eksperimen. Penelitian ini melibatkan dua kelompok sampel yang terdiri dari kelompok kontrol dan kelompok eksprerimen. Menurut Cresswell (2015) metode penelitian kuasi eksperimen terdiri dari beberapa jenis desain yang semuanya memiliki kekuatan dan kelebihan. Desain penelitian yang digunakan oleh peneliti adalah desain yang memiliki rancangan Pretest-Posttest Control Group Design. Dalam penelitian ini Pretest diberikan diawal sebelum pembelajaran sedangkan posttest diberikan diakhir setelah semua pembelajaran selesai dilaksanakan.

Populasi yang dipilih dalam penelitian ini adalah seluruh siswa-siswi kelas V Sekolah Dasar pada semester genap tahun ajaran pendidikan 2017/2018 di wilayah Kecamatan Cileunyi Kabupaten Bandung. Peneliti menetapkan salah satu sekolah dasar swasta di kabupaten bandung sebagai sampel penelitian. Pemilihan sampel dilakukan tidak secara random, melainkan sampel dipilih berdasarkan teknik sampling insidental. Adapun Sampling insidental merupakan suatu teknik penentuan sampel yang berdasarkan pada suatu kebetulan dan disesuaikan dengan kebutuhan dalam artian sampel memiliki kesesuaian dengan penelitian yang akan dilaksanakan. SD swasta tersebut dipilih dan ditentukan sebagai sampel penelitian oleh peneliti dikarenakan SD tersebut memiliki banyak kelas paralel dengan kemampuan akademik yang homogen atau hampir sama. Selain itu, SD tersebut sekolah yang masih menggunakan dan konsisten untuk menerapkan Kurikulum 2013 dan menjadi Sekolah Model Kurikulum 2013.

\section{HASIL DAN PEMBAHASAN}

Hasil dalam penelitian ini mengambil data gain sebagai salah satu indikator dalam mengukur efektivitas pembelajaran. Adapaun nilai hasil gain penalaran matematis dapat dilihat pada Tabel 2 berikut:

Tabel 2. Nilai Penalaran Matematis

\begin{tabular}{ccccccc}
\hline \multicolumn{7}{c}{ Descriptive Statistics } \\
\hline Skor Pretest & $N$ & Minimum & $\begin{array}{c}\text { Maximu } \\
m\end{array}$ & Sum & Mean & $\begin{array}{c}\text { Std. } \\
\text { Deviatio } \\
n\end{array}$ \\
\hline $\begin{array}{c}\text { Kelas } \\
\text { Eksperimen }\end{array}$ & 24 & 66,7 & 100 & 1904 & 79,32 & 9,2 \\
\hline Kelas Kontrol & 24 & 45,8 & 68,7 & 1372 & 57,15 & 7,0 \\
\hline
\end{tabular}


Berdasarkan Tabel 2 di atas, dapat dilihat bahwa peningkatan kemampuan siswa kelas eksperimen dan kelas kontrol berbeda jauh. Hal ini dapat dilihat dari perolehan ratarata skor kelas eksperimen sebesar 79,32 dan rata-rata skor kelas kontrol 57,15. Terlihat bahwa rata-rata skor gain kelas eksperimen lebih besar dibandingkan dengan rata-rata skor gain kontrol dengan selisih 22,17. Selain itu, pada kelas eksperimen ditemukan siswa yang memiliki nilai gain 100. Hal tersebut menggambarkan bahwa pembelajaran pada kelas eksperimen dapat meningkatkan kemampuan penalaran matematis siswa secara signifikan. Dalam mengukjur signifikansi perbedaan, maka akan dilakukan uji perbedaan rerata pada hasil gain tersebut. Adapun hipotesis nol dan hipotesis tandingan yang digunakan yaitu:
$\mathrm{H}_{0}: \mu_{1} \leq \mu_{2}$, peningkatan kemampuan siswa kelompok 1 tidak lebih baik dari daripada kelompok 2
$\mathrm{H}_{\mathrm{a}}: \mu_{1}>\mu_{2}$, peningkatan kemampuan siswa kelompok 1 lebih baik dari daripada kelompok 2

Tabel 3. Hasil Uji Perbedaan Rerata Gain Penalaran

\begin{tabular}{ccccl}
\hline & $\begin{array}{c}\text { Sig. } \\
(2 \\
\text { tailed })\end{array}$ & $\begin{array}{c}\text { Sig. } \\
(1 \text { tailed })\end{array}$ & Keputusan & Keterangan \\
\hline PJBL - & 0.000 & 0.000 & $\mathrm{H}_{0}$ ditolak & $\begin{array}{l}\text { Peningkatan } \\
\text { kemampuan } \\
\text { Konvensional }\end{array}$ \\
& & & & $\begin{array}{l}\text { penalaran PjBL } \\
\text { - Literasi lebih } \\
\text { baik daripada } \\
\end{array}$ \\
& & & \\
& & & konvensional. \\
\hline
\end{tabular}

Dari hasil pengujian hipotesis secara statistic pada Tabel 3 menjelaskan bahwa terdapat perbedaan kemampuan penalaran matematis siswa yang memperoleh pembelajaran PJBL-literasi dengan Konvensional. Model PJBL-Literasi merupakan model yang lebih baik dalam memfasilitasi peningkatan kemampuan penalaran matematis siswa dibandingkan dengan pembelajaran konvensional. Dalam penentuan efektivitas, ada tiga hal yang dilihat yaitu skor rata-rata diatas KKM, rata-rata gain, dan ketuntasan belajar. Pembelajaran PJBL-literasi memiliki skor rata-rata 80, gain 79 dan ketuntasan belajar $83 \%$. Hal ini dapat diasumsikan bahwa pembelajaran berbasis proyek literasi sudah efektif, karena skor rata-rata lebih dari KKM $(80>70)$, gain dalam kategori tinggi dan ketuntasan belajar lebih dari $80 \%$.

Peningkatan kemampuan penalaran matematis siswa pada kelas eksperimen terdapat perbedaan dengan kemampuan penalaran matematis siswa pada kelas kontrol, hal ini disebabkan karena pada kelas eksperimen proses pembelajaran selalu menekankan pada proses berpikir tingkat tinggi yang menuntut adanya proses berpikir secara terus menerus. Hal tersebut sangat sesuai dengan pendapat Eggen \& Kauchak (2012) yang menjelaskan bahwa pembelajaran yang bagus harus bermakna dengan cara memberikan konteks kehidupan sehari-hari di dalam pembelajaran.

Model PJBL-Literasi pun memberikan pengaruh yang baik di dalam memfasilitasi peningkatan kemampuan penalaran matematis siswa. Pada pembelajaran ini siswa sangat senang dan aktif dalam pembelajaran terutama dalam kegiatan literasi yang membuat 
kemampuan mereka meningkat dengan signifikan. Hal ini sangat sesuai dengan hasil penelitian Tai, Leou, \& Hung (2014) yang menjelaskan bahwa literasi sangat penting dalam pembelajaran matematika dikarenakan hal tersebut dapat meningkatkan kemampuan dan pemahaman siswa dalam menguasai konsep materi matematika.

Pembelajaran dengan Model PJBL-literasi membuat siswa senang, dikarenakan siswa mempunyai proyek yang harus dikerjakan. Siswa belajar dengan mengaitkan materi matematika dengan kehidupan nyata melalui kegiatan membuat proyek literasi. Kegiatan tersebut dapat dlihat pada Gambar 1 di bawah ini.
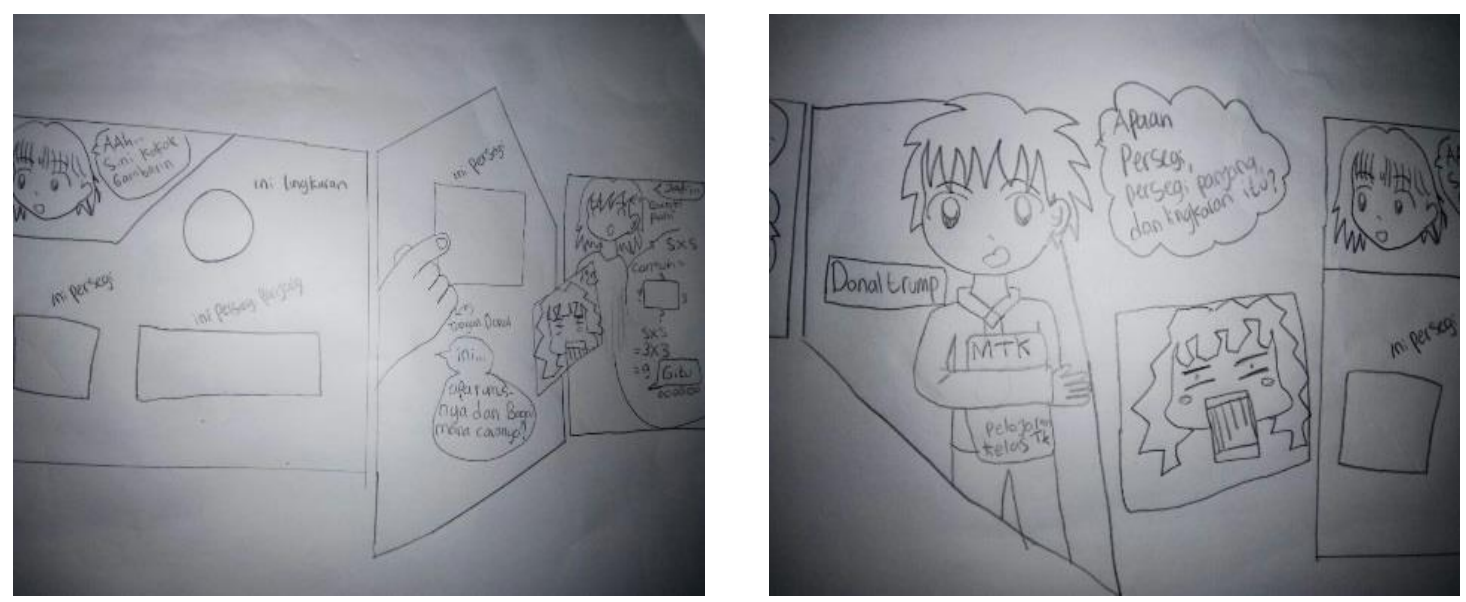

Gambar 1. Komik karya PJBL-Literasi

Pada pembelajaran dengan Model PJBL-Literasi siswa sangat difasilitasi dalam kemampuan penalaran matematis. Hal tersebut terlihat dari kegiatan-kegiatan yang selalu adanya tuntutan untuk kemampuan penalaran dalam setiap tahap pembelajaran PJBLliterasi. Hal tersebut sangat sesuai dengan penelitian Levenberg (2015) yang menjelaskan bahwa kegiatan literasi dapat meningkatkan kepekaan siswa terhadap konteks sekitar dan dapat meningkatkan pemahaman siswa terhadap materi matematika.

\section{SIMPULAN DAN REKOMENDASI}

Terdapat perbedaan peningkatan kemampuan penalaran matematis antara siswa yang memperoleh pembelajaran menggunakan pembelajaran berbasis proyek literasi dan pembelajaran konvensional. Pembelajaran berbasis proyek literasi merupakan model pembelajaran yang baik dan efektif dalam memfasilitasi siswa dalam meningkatkan kemampuan penalaran matematis. Hal tersebut dikarenakan siswa diajak untuk mencari solusi dari suatu permasalahan melalui kegiatan literasi.

Dalam konteks penelitian, peneliti menganjurkan untuk meneliti lebih lanjut terkait model PJBL-Literasi, melihat hasil penelitian yang menunjukkan bahwa model ini sangat bisa membuat siswa kreatif dan senang dengan tidak mengesampingkan esensi materi yang disampaikan.

\section{DAFTAR PUSTAKA}

Abidin, Z. (2016). Mathematical learning activity using connecting organizing reflecting extending (core) model to improve mathematical connection skill. Proceeding International Conference and Technology, UM Malang, 2, 68-79. 
Abidin, Z \& Jupri, A. (2017). The use of multiliteration model to improve mathematical connection ability of primary school on geometry. International E-Journal of Advances in Education, 3 (9), 603-610.

Bhargava, D. R. (2016). Effect of problem based learning model on achievement in social sciences. International Journal of Science and Research (IJSR), 5(5), 699-701.

Bill, V. \& Jamar, I. (2010). Diciplinary literacy in mathematics classroom dalam conten matters : a disciplinary literaxy approach to improving student learning. San Fransisco : Jossey-Bass A wiley Imprint.

Concannon-Gibney, T. \& McCarthy, M.J.(2012). The explicit teaching of reading comprehension in science class: a pilot professional development program. Improving Schools, 15 (1), 73-88.

Cresswell, J. (2015). Riset pendidikan : perencanaan, pelaksanaan, dan evaluasi riset kualitatif dan kuantitatif. Yogyakarta : Pustaka Pelajar

Eggen P, dan Kauchak D. (2012). Strategi dan model pembelajaran. Jakarta: Indeks.

Etherington, M.B. (2011). Investigative primary science: a problem-based learning approach. Austr. J. Teacher Educ, 36 (9), 36-57.

Firdaus, M.F., Wahyudin., \& Herman, T. (2017). Improving primary students' mathematical literacy through problem based learning and direct instruction. Academic Journal, 12 (4), 212-219.

Ivanic, R. (2009). Bringing literacy studies into research and prospects dalam the future of literacy studies. New York: Palgrave MacMillan.

Joyce, B., Weil, M., \& Calhoun, E. (2009). Models of teaching: model-model pengajaran (edisi 8). Yogyakarta: Pustaka Pelajar.

Kemendikbud (2016). Revisi kurikulum 2013 : matematika dipisahkan dari tematik. [Online]. Tersedia: http:/kemendikbud.go.id/kemdikbud/.

Levenberg, I. (2015). Literacy in mathematics with "mother goose". Int. J. Learn. Dev, 5 (1,) 27-32.

Mahdiansyah dan Rahmawati (2014). Mathematical literacy of students at secondary education level: an analysis using international test design with indonesian context. J. Pendidikan dan Kebudayaan, 20 (4):452-469.

McConachi, S.M., et al. (2010). Content matters: a disciplinary literacy approach to improving student learning. San Fransisco: Jossey-Bass A Wiley Imprint.

McKee, J. \& Ogle, D. (2005). Interesting instruction literacy and science. New York: The Guilford Press.

NCTM (2012). Principles and standars for school mathematics volume 1. Michigan: National Council of Teachers of Mathematics.

Olge, D. Et al. 920070. Buliding literacy in social studies : strategies for improving comprehension and critical thinking. Alexandria : ASCD.

Rahman (2018). Kecakapan literasi di sekolah dasar. Disampaikan Dalam Workshop dan Seminar Nasional Mengembangkan Literasi Anak Disleksia di Sekolah Dasar Inklusif. 21 Juli 2018.

Shyyan, et al (2008). Instructional strategies for improving achievement in reading, mathematics, and science for english languange learners. Assesment for Effective Intervention, 33 (3), 145-155.

Swanson, E., et al. (2011). Applying a cohesive set of comprehension strategies to content area instruction. Intervention in School and Clinic, 46 (5), 266-272.

Tai C.H., Leou, S., \& Hung J.F (2014). Mathematical literacy of indigenous students in taiwan. Int. Res. J. Sustain. Sci. Eng, 2 (3), 1-5. 
Tan, M. (2011). Mathematics and science teachers' beliefs and practices regarding the teaching of languange in content learning. Languange Teaching Reasearch. 15 (3), 325-342.

Trilling, B. \& Fadel, C. (2009). $21^{\text {st }}$ century skills. San Fransisco : Jossey-Bass A wiley Imprint. 